\title{
Direct Oxidation of Ethylene Glycol on PtSn/C for Application in Alkaline Fuel Cell
}

\author{
Letícia L. de Souza ${ }^{1}$, Almir Oliveira Neto ${ }^{2}$, Christina A. L. G. de O. Forbicini ${ }^{1, *}$ \\ ${ }^{1}$ Centro de Química e Meio Ambiente, \\ ${ }^{2}$ Centro de Células a Combustível e Hidrogênio, Instituto de Pesquisas Energéticas e Nucleares, Av. \\ Prof. Lineu Prestes, 2242 - Cidade Universitária - CEP 05508-000 - São Paulo-SP - Brasil \\ E-mail: cforbici@ipen.br
}

doi: $10.20964 / 2017.12 .57$

Received: 19 June 2017 / Accepted: 4 September 2017 / Published: 12 November 2017

\begin{abstract}
$\mathrm{PtSn} / \mathrm{C}$ electrocatalysts with different molar ratios were synthesized by borohidrate process for glycol ethylene oxidation. All electrocatalysts were, also, characterized by X-ray diffraction (XRD), transmission electronic microscopy (TEM), attenuated total reflectance Fourier transform infrared spectroscopy (ATR-FTIRS), energy dispersive X-ray (EDX), while the electrochemical activities of those materials were evaluated by cyclic voltammetry, chronoamperometry and polarization curves in Direct Ethylene Glycol Alkaline Fuel Cells (DEGAFC). TEM results for $\mathrm{PtSn} / \mathrm{C}$ electrocatalysts showed crystallite size of $4 \mathrm{~nm}$. The curves of power density indicated that $\mathrm{PtSn} / \mathrm{C}$, with molar ratio of 70:30, presented the best results for glycol ethylene oxidation, in comparison with other alternatives prepared. These results may be associated to the selectivity to form oxalate or a bifunctional mechanism (oxygenated species from $\mathrm{Sn}$ ).
\end{abstract}

Keywords: PtSn/C electrocatalysts, ethylene glycol oxidation, alkaline fuel cell, ATR-FTIRS in situ.

\section{FULL TEXT}

(C) 2017 The Authors. Published by ESG (www.electrochemsci.org). This article is an open access article distributed under the terms and conditions of the Creative Commons Attribution license (http://creativecommons.org/licenses/by/4.0/). 